\title{
Beneficial Impact of Kisan Credit Card on Crop Production and Productivity in Selected Districts of Haryana, India
}

\author{
Madhu Ahlawat and Sumita Singh* \\ Baba Mastnath University, Rohtak, Haryana 124021, India \\ *Corresponding author
}

\section{A B S T R A C T}

\begin{tabular}{|l|}
\hline K e y w o r d s \\
$\begin{array}{l}\text { Production, } \\
\text { Productivity, } \\
\text { Farmer's Income }\end{array}$ \\
\hline Article Info \\
\hline $\begin{array}{l}\text { Accepted: } \\
\text { 28 June 2020 } \\
\text { Available Online: } \\
\text { 10 July 2020 }\end{array}$ \\
\hline
\end{tabular}

A field study was conducted during June 2019 to June 2020 at different locations of the haryana district to find out the utilization pattern of kisan credit card by the farmers, to analyze the constraints faced by the farmers while issuing of $\mathrm{KCC}$ and repayment of loan and the strategies to overcome these constraints, to analyze the impact of KCC on the enhancement in agricultural production. And to analyze the impact of KCC on the enhancement of allied activities. Banks, branches and types of farmers (on the basis of different classification such as age group, land holding, level of literacy, family type etc.), agriculture are in the villages will be used as source of information and it will make three stages of sample selection within the selected district (Rohtak). Rohtak district was purposively selected for the research study due to varied climatic conditions and different crop growing farmers were available as well as having good progress in implementing $\mathrm{KCC}$ scheme. The results of the study reveals that KCC beneficiery farmers have obtained higher production, productivity and net profit when compared with $\mathrm{KCC}$ non beneficiery farmers.

\section{Introduction}

Agriculture sector is the mainstream of Indian economy and the most important sector of the Indian Economy When any change in the agriculture sector-"positive or negative"- has multiple effect on the entire economy Therefore; the sustainable development of agriculture is the most important for acceleration in the Indian economy. Agriculture development is influenced by several factors like as irrigation, market, infrastructure and credit. Out of these factors credit is crucial input for sustainable development of agriculture. Government of
India has been taken several steps in context of agriculture credit. Kisan Credit Card is one of them. S.Rajamohan and K.Subha (2014). This scheme has facilitated the availability of credit in time and has simplified the procedure for availing loan from banks to a large extent (Nahatkar et al., 2002).Credit is an important component in agriculture with crop loans constituting a major portion of disbursements.

The Kisan Credit Card Scheme was introduced in India in 1998- 99 by then finance minister yashwant sinha. Kallur, M.S. (2005). Consequent to this NABARD 
has prepared a model kisan credit card scheme in consultation with the major banks on the basis of $\mathrm{R} \mathrm{V}$ GUPTA Committee. Kisan credit card has emerged as a new and vital delivery mechanism to meet the credit requirements of the farmers in a suitable and hassle free manner. The salient features of $\mathrm{KCC}$ are as each farmer will be sanctioned a revolving cash credit facility for meeting the expenses related to crop cultivation allowing any number of drawals and repayments within the limit. The farmer is provided with a Kisan Credit Card in the form of a passbook or an identity card cum-pass book. The KCC is not a electronic credit or debit card.The limit under $\mathrm{KCC}$ will cover (a) entire production credit needs for full year (on the basis of peak crop credit requirement), (b) credit for ancillary activities related to crop production and allied activities, (c) credit needs of nonfarm activities, if any and (d) certain percentage of production credit for consumption purposes. The KCC to be valid for 3 years subject to annual review by the financing bank. The KCC holder may make as any number of drawals and repayments in the account as feasible. However each drawal/disbursement to be repaid within 12 months. In case of damage to crops due to occurrence of natural calamities, conversion / re-scheduling of loans also permissible. If a farmer cultivates Kharif crop and Rabi crop peak credit requirement will be the sum of the limits essential for the two seasons as the costs of the Rabi crop would have started much before the kharif crops are marketed. If a farmer has Kharif, Rabi and Perennial crop then the peak credit requirement will be arrived on the basis of the projected cash flows from farming operations. Notified crops cultivated by the farmer with credit support under KCC shall be covered by crop insurance. Banks may make arrangement with vendors to issue input on the basis of the KCC and seek reimbursement from the bank.

The sustained and rapid growth in agriculture can be achieved mainly through an increase in productivity which is only possible through provision of adequate and timely credit, on the one hand, and accelerated development and dissemination of improved technologies, on the other (Singh, A and Sihag, S. (2018) In order to produce more, the farmers need to spend more on modem inputs, which must be financed either out of savings or through borrowings. Since the amount of savings by the farmers is very poor, an increased institutional credit flow is essential for faster agricultural growth. Sharma (2006) revealed that higher percentage 45.00 percent of the respondents belonged to medium annual income category. Sowjanya (2007) reported that majority $(57.14 \%)$ of the respondents belonged to medium income groups, while 71.42 per cent of the respondents belonged to low income category groups. Parmar (2008) reported that a higher percentage of the beneficiaries $(43.33 \%)$ had medium level of annual income. The net profit was 24120.11 per hectare in case of $\mathrm{KCC}$ beneficiaries and 23551.34 per hectare in case of non-KCC beneficiaries. Hooda, V.S. (2011).

\section{Materials and Methods}

The following stepwise procedure has been done to carry our research

\section{Study of background information of the location}

Banks, branches and types of farmers (on the basis of different classification such as age group, land holding, level of literacy, family type etc.), agriculture are in the villages will be used as source of information and it will make three stages of sample selection within the selected district (Rohtak). Rohtak district was purposively selected for the research study due to varied climatic conditions and different crop growing farmers were available as well as having good progress in 
implementing KCC scheme.

The problem of the area regarding KCC

Selection of samples:-

\section{Primary Data}

The basic information regarding the KCC's collected through in-depth interview from the by the help of Branch Manager and credit manager.

\section{Secondary Data}

NABARD and other bank's financial reports of last three years \& Circulars of RBI

3) Variables used in study: the following mentioned variables will be studied for easy classification and understanding the cause of the constraints of the KCC

Age

Education

Family background

Family type

Size of land holdings

Annual income

Attitude towards $\mathrm{KCC}$

Knowledge about KCC
Sampling design: multistage sampling design will be used for selection of sample for study. The data will be collected with the help of pre-tested questionnaires.

\section{Processing of data}

editing: - to detect errors and omissions coding and tabulation categorization of data

Statistical tool: Mean, mode, percentage, standard deviation, range, percentage share and growth rate.

\section{Results and Discussion}

From the table 1, depicted above, it was clearly found that farmers who had availed KCC obtained higher gross reurn, family labour income and ultimately net return in all the crops. Also in the second table productivity of the crops for KCC holders farmers was found higher as compared to non KCC farmers for all categories of farmers i.e. small $(<1$ hactare), medium(1-2 hactare) and large farmers ( $>2$ hactares). In table 3 also the similar trend was observed. Here we have combined our sampling observations on all categories of farmers for both KCC and non KCC farmers.

Table.1 Returns over costs for KCC beneficiary and non KCC farmers in ROHTAK

\begin{tabular}{|c|c|c|c|c|}
\hline Particulars & Small farmers & Medium farmers & Large farmers & Total \\
\hline \multicolumn{5}{|c|}{ Beneficiery Farmer } \\
\hline Area & 90 & 90 & 90 & 270 \\
\hline productivity & 19.51 & 19.97 & 20.6 & 20.02 \\
\hline \multicolumn{5}{|c|}{ Non-Beneficiery Farmer } \\
\hline Area & 90 & 90 & 90 & 270 \\
\hline productivity & 17.8 & 18.16 & 19.4 & 18.82 \\
\hline $\begin{array}{l}\% \text { change in } \\
\text { productivity }\end{array}$ & 9.61 & 9.97 & 6.19 & 8.59 \\
\hline
\end{tabular}


Table.2 Impact of Kisan Credit Card Scheme on Agricultural Production and Productivity of Wheat Crop in District Karnal

\begin{tabular}{|l|l|l|l|l|l|l|l|l|}
\hline \multirow{2}{*}{ Particulars } & \multicolumn{3}{|l|}{ Paddy } & Maize & \multicolumn{2}{l|}{ Wheat } & \multicolumn{2}{l|}{ Potato } \\
\cline { 2 - 10 } & $\begin{array}{l}\text { BENEFIC } \\
\text { IARY }\end{array}$ & $\begin{array}{l}\text { NON- } \\
\text { BEN. }\end{array}$ & $\begin{array}{l}\text { BENEFI } \\
\text { CIARY }\end{array}$ & $\begin{array}{l}\text { NON- } \\
\text { BEN. }\end{array}$ & $\begin{array}{l}\text { BENEFIC } \\
\text { IARY }\end{array}$ & $\begin{array}{l}\text { NON- } \\
\text { BEN. }\end{array}$ & $\begin{array}{l}\text { BENEFI } \\
\text { CIARY }\end{array}$ & $\begin{array}{l}\text { NON- } \\
\text { BEN. }\end{array}$ \\
\hline Gross Returns & 24020 & 21044 & 21536 & 19366 & 21986 & 18876 & 56060 & 44836 \\
\hline $\begin{array}{l}\text { Family Labour } \\
\text { Income }\end{array}$ & 7516 & 6209 & 6241 & 5678 & 7244 & 5688 & 28233 & 15938 \\
\hline Net Return & 8420 & 7158 & 6679 & 6288 & 7211 & 4218 & 26112 & 16522 \\
\hline
\end{tabular}

Table.3 Comparison of productivity and returns before and after taking $\mathrm{KCC}$

\begin{tabular}{|l|l|l|}
\hline Parameters & Before taking KCC & After taking KCC \\
\hline \multicolumn{3}{|c|}{ Marginal farmers (0-2.5 acres) } \\
\hline Productivity (q./ha.) & 40 & 43.50 \\
\hline Gross income (Rs/ha.) & 51450.50 & 68120.40 \\
\hline Net income (Rs/ha.) & 16302 & 24800 \\
\hline \multicolumn{3}{|c|}{ Small farmers (2.5-5 acres) } \\
\hline Productivity (q./ha.) & 40.20 & 43.70 \\
\hline Gross income (Rs/ha.) & 51707 & 68433.59 \\
\hline Net income (Rs/ha.) & 16383.51 & 24914.02 \\
\hline \multicolumn{1}{|c|}{ Productivity (q./ha.) } & Large farmers (>5 acres) & \\
\hline Gross income (Rs/ha.) & 40.73 & 44.00 \\
\hline Net income (Rs/ha.) & 52389.47 & 68903.39 \\
\hline & 16599.51 & 25085.05 \\
\hline
\end{tabular}

In conclusion:-

The results of the study would be useful to the farmers of ROHTAK in particular and of HARYANA in general, identifying the KCC scheme progress, impact, utility, constraints at the farmer level.

The findings would be helpful to the farmers for making appropriate decisions and how best the available credit resources could be judiciously utilized for increased farm income.

This study would be useful for financial institutes to assess the financial needs of the farmers and their constraints in availing loans.

At the micro level this study also guides the farmers to depend upon financial sources of loans rather than noninstitutional sources and helpful to the planners, administrators and research workers for better planning and implementation.

From this research the observed data could be utilized to know the various constraints responsible for the success of the $\mathrm{KCC}$

The observed data will help in understanding, what are the various changes that is needed at credit institutional level for the easy availment as well as repayment of the loan.

Ultimately this research will be helpful in the betterment of the farmers as a unit and country as a whole. 


\section{References}

Hooda, V.S. (2011). Kisan Credit Card Scheme: A Success Story. Kurukshetra. 59(8): 19 - 22.

Kallur, M.S. (2005), "Impact of Kisan Credit Card on Flow of Credit and Repayment Rate in a Backward Region : A case of Agricultural Development Bank of ShorapurTaluka, Gulbarga District, Karnataka State, "Indian Journal of Agricultural Economics. 60(3): 396

Nahatkar, S.B., Mishra, P.K., Raghuwanshi, N.K. and Beohar, B.B. (2002) An evaluation of Kisan Credit Card scheme: A case study of Patan tehsil of Jabalpur district of Madhya Pradesh, Indian Journal of Agricultural Economics, 57(3): 578.

Parmar, S.K. (2008). A study on repayment behaviour of beneficiaries of Kisan Credit Card scheme in Sehore block of Sehore district of Madhya Pradesh. M.Sc. (Ag) Thesis submitted to
J.N.K.V.V. Jabalpur.

Rajamohan S and Mrs.K.Subha K. (2014). Kisan Credit Card Scheme in India: a Facet of Financial Inclusion International Journal of Scientific Research. 3(10): $2277-8179$

Sharma, S.K. (2006). A study on functioning of Kisan Seva Kendras (KSKs) in Udaipur district of Rajasthan. M.Sc. (Agri.) Thesis, University of Agricultural Sciences, Dharwad.

Singh, A and Sihag, S. (2018). Impact of kisan credit card scheme on farm economy of farmers in karnal district with special reference to wheat crop. International educationa and research journal, 4(5): 2454-9916.

Sowjanya (2007). A comparative analysis of successful and unsuccessful selfhelp groups in Gadag District of Karnataka. M.Sc. (Agri.) Thesis, University of Agricultural Sciences, Dharwad.

\section{How to cite this article:}

Madhu Ahlawat and Sumita Singh 2020. Beneficial Impact of Kisan Credit Card on Crop Production and Productivity in Selected Districts of Haryana. Int.J.Curr.Microbiol.App.Sci. 9(07): 3938-3942. doi: https://doi.org/10.20546/ijcmas.2020.907.462 